UDC 332; DOI 10.18551/rjoas.2022-01.16

\title{
THE LEVEL OF FARMERS' BEHAVIOR AND ITS CORRELATION TO RICE FARMING INCOME IN TIDAL LOW LANDS, SOUTH SUMATERA, INDONESIA
}

\author{
Honorita Bunaiyah*, Yazid Muhammad, Riswani \\ Master's Program of Agribusiness, Faculty of Agriculture, University of Sriwijaya, Indonesia \\ *E-mail: bunaiyahhonorita@gmail.com
}

\begin{abstract}
The government's commitment to increase rice production requires a breakthrough of effort. One of the strategies is to make tidal low lands as a production area. Indonesian Agency for Agricultural Research and Development has produced and developed various technological innovations to increase rice production and production input efficiency in tidal low lands, one of which is the Integrated Crop Management Approach (ICM). This study aims to analyze the correlation between the level of behavior of farmers in rice cultivation with the ICM approach with rice farming income in tidal low lands. The research was conducted in Muara Telang District, Banyuasin Regency, South Sumatera Province in 2021 on 150 respondents. The study used a survey method with direct interviews with respondents. The results showed that the level of behavior of farmers in rice cultivation with the ICM approach was at a high criteria. Farming income earned is Rp. $25,226,096 / \mathrm{Ha} / Y$ ear. The results of the analysis also conclude that there is a significant and positive correlation between the level of farmer behavior and the income of rice farming in tidal low lands as big as $45.8 \%$. The higher farmers' behavior, the greater farmers obtained the income.
\end{abstract}

\section{KEY WORDS}

Behavior, income, Integrated Crop Management, tidal low lands.

Tidal low land is categorized as suboptimal land due to various existing constraints, both biophysical (physico-chemical) as well as socio-economic and institutional (Ananto et al., 2000). Indonesian Agency of Agricultural Research and Development (2007) reports that tidal low lands have been cultivated as a rice-based farming, which is combined with citrus, coconut, and other crops traditionally by Banjar and Bugis farmers along the coast and riverbanks of Kalimantan and Sumatera since hundreds of years ago.

The utilization of tidal low lands in South Sumatra have not been optimal due to various obstacles. The indications can be seen from the level of productivity which is still low, for example in 2018 the productivity was 5.16 tons/ha, lower than the national which reached 5,203 tons/ha (Central Bureau of Statistic of South Sumatera, 2019). Farmers' rice productivity in tidal low land varies widely, depending on the variety planted, seed quality, cultivation technology, disturbance of plant-disturbing organisms, land typology and characteristics of overflow or waterlogging. Alihamsyah et al. (2003) stated that the productivity of tidal low land can still be increased by carrying out appropriate land management such as the provision of ameliorant material, fertilization, the use of varieties that are in accordance with land conditions and the right land preparation system.

The government's commitment to increase rice production requires a breakthrough of effort. One of the strategies is to make tidal low lands as a production area. Although technically it is classified as sub-optimal with constraints on the physical and chemical properties of the soil including soil acidity, this land is prospective as productive agricultural land (Suriadikarta and Sutriadi, 2007). Technological improvements generated through research and assessment are sought to solve actual problems in the field. Indonesian Agency for Agricultural Research and Development has produced and developed various technological innovations, one of which is the Integrated Crop Management Approach (ICM), which is able to increase rice production and production input efficiency.

ICM is a new agricultural technology innovation which is an integration of several previous agricultural technology components by reflecting location-specific aspects, 
problems faced (demand driven technology), where the technological components are determined together with farmers. Furthermore, the ICM technology package also requires the use of organic fertilizers. It is also intended to increase farm productivity and efficiency.

The application of rice cultivation in tidal low land with the ICM approach is reflected by the level of farmers' behavior. Behavior describes how the level of farmers' knowledge which then deliver to a positive attitude and then configure skilled of farmers. Pratiwi and Sudrajat (2012) stated that the behavior of farmers in farming includes processing, seeding, fertilizing, irrigation, weeding, pest and disease control and weeding. The behavior of farmers in managing and maintaining paddy fields reflects the management of agricultural land. According to Fadhillah, et al. (2019), behavior is an action that can actually be observed.

The behavior of farmers in cultivation technology with the ICM approach is thought to have an effect on rice farming income in tidal low lands. This study aims to analyze the level of behavior of farmers and its correlation to farmers' income in tidal low lands of South Sumatera.

\section{METHODS OF RESEARCH}

This research was conducted in Muara Telang District, Banyuasin Regency, South Sumatera Province. The choice of place was done purposively with the consideration that Muara Telang District is one of the centers of tidal low lands in Banyuasin Regency which tends to be able to reflect rice cultivation in tidal low lands of Banyuasin Regency with the widest harvest area of tidal low lands in Banyuasin Regency $(41,678.9 \mathrm{Ha})$ with an average productivity of 5.07 tons/ha (Central Bureau Statistic of Banyuasin Regency, 2018).

The method used in this study is a survey method to obtain accurate information and descriptions of the level of farmers' behavior and income in tidal low land in Muara Telang District, Banyuasin Regency. Surveys produce information that is statistical in nature and is a basic form of quantitative. Survey research asks several respondents about their beliefs, opinions, characteristics, and behaviors that have occurred or are currently occurring (Groves, 2010).

The collection of data, information and field facts are carried out directly through interviews using a list of questions and followed by in-depth interviews with key informants, both orally and in writing that require face-to-face contact between researchers and respondents (Ruslan, 2006). The sampling method used in this study is a simple random sampling with a total sample of 150 tidal low land farmers. This technique is used to provide equal opportunities for the population to be selected as research samples (Rawung, 2020).

Table 1 - Values Indicator of Knowledge, Attitude and Skill Level of Farmers in Tidal Low Lands Rice Cultivation with the ICM Approach

\begin{tabular}{|c|c|c|c|c|c|c|c|}
\hline No. & Indicator & $\begin{array}{l}\text { Number of Statement } \\
\text { Items }\end{array}$ & NST & NSR & JIK & NR & $\mathrm{PI}$ \\
\hline 1. & $\begin{array}{l}\text { New Superior Varieties (VUB) as well as quality } \\
\text { and labeled seeds }\end{array}$ & 5 & 15 & 5 & 3 & 10 & 3.33 \\
\hline 2. & Land preparation & 2 & 6 & 2 & 3 & 4 & 1.33 \\
\hline 3. & Planting & 2 & 6 & 2 & 3 & 4 & 1.33 \\
\hline 4. & Micro water management & 2 & 6 & 2 & 3 & 4 & 1.33 \\
\hline 5. & Balanced fertilization & 3 & 9 & 3 & 3 & 6 & 2.00 \\
\hline 6. & Amelioration & 1 & 3 & 1 & 3 & 2 & 0.67 \\
\hline 7. & Pest and Deseases Control & 1 & 3 & 1 & 3 & 2 & 0.67 \\
\hline 8. & Harvest & 2 & 6 & 2 & 3 & 4 & 1.33 \\
\hline
\end{tabular}

Calculations to make class intervals on each indicator of farmers' behavior (knowledge, attitude and skill) in tidal low land farming using the ICM approach are measured by 8 (eight) statement items: (1) New superior varieties (VUB) and quality and labeled seeds, (2) Land preparation, (3) Planting, (4) Micro water management, (5) Balanced fertilization based on plant needs and soil nutrient status, (6) Amelioration, (7) Plant Pests and Deseases control, and (8) Harvest (Table 1). The question items for each indicator were measured using a 
scoring weighting of 1-3: 1 (low), 2 (medium), and 3 (high), then tabulated and processed using a Likert Scale (Table 2 and Table 3) with the formula (Nasution and Barizi in Rambe and Honorita, 2011):

$$
\begin{gathered}
N R=N S T-N S R \\
P I=N R: \text { JIK }
\end{gathered}
$$

Where: NR = Value Range; NST = Highest Score Value; NSR = Lowest Score Value; $\mathrm{PI}=$ Interval Length; JIK = Number of Class Intervals.

Table 2 - Class Interval Values Each Indicator to Measurement of Farmers' Behavior Level in Tidal

\begin{tabular}{|c|c|c|c|}
\hline No. & Indicator & $\begin{array}{c}\text { Class Interval Value (Per } \\
\text { Indicator) }\end{array}$ & $\begin{array}{l}\text { Value } \\
\text { Criteria }\end{array}$ \\
\hline 1. & $\begin{array}{l}\text { New Superior Varieties (VUB) as well as quality and } \\
\text { labeled seeds }\end{array}$ & $\begin{array}{c}15.00 \times 24.99 \\
24.99<x 34.98 \\
34.98<x 45.00\end{array}$ & $\begin{array}{l}\text { Low } \\
\text { Medium } \\
\text { High }\end{array}$ \\
\hline 2. & Land preparation & $\begin{array}{c}6.00 \times 9.99 \\
9.99<\times 13.98 \\
13.98<\times 18.00\end{array}$ & $\begin{array}{l}\text { Low } \\
\text { Medium } \\
\text { High }\end{array}$ \\
\hline 3. & Planting & $\begin{array}{c}6.00 \times 9.99 \\
9.99<x 13.98 \\
13.98<x 18.00\end{array}$ & $\begin{array}{l}\text { Low } \\
\text { Medium } \\
\text { High }\end{array}$ \\
\hline 4. & Micro water management & $\begin{array}{c}6.00 \times 9.99 \\
9.99<\times 13.98 \\
13.98<x 18.00\end{array}$ & $\begin{array}{l}\text { Low } \\
\text { Medium } \\
\text { High }\end{array}$ \\
\hline 5. & Balanced fertilization & $\begin{array}{c}9.00 \times 15.00 \\
15.00<x 21.00 \\
21.00<x 27.00\end{array}$ & $\begin{array}{l}\text { Low } \\
\text { Medium } \\
\text { High }\end{array}$ \\
\hline 6. & Amelioration & $\begin{array}{c}3.00 \times 4.98 \\
4.98<\times 6.99 \\
6.99<\times 9.00\end{array}$ & $\begin{array}{l}\text { Low } \\
\text { Medium } \\
\text { High }\end{array}$ \\
\hline 7. & Pest and Deseases Control & $\begin{array}{c}3.00 \times 4.98 \\
4.98<\times 6.99 \\
6.99<\times 9.00\end{array}$ & $\begin{array}{l}\text { Low } \\
\text { Medium } \\
\text { High }\end{array}$ \\
\hline 8. & Harvest & $\begin{array}{c}6.00 \times 9.99 \\
9.99<x 13.98 \\
13.98<x 18.00\end{array}$ & $\begin{array}{l}\text { Low } \\
\text { Medium } \\
\text { High }\end{array}$ \\
\hline
\end{tabular}
Low Lands Rice Cultivation with the ICM Approach

Table 3 - Value Class Interval of Scores Total and Each Question to Measurement of Farmers' Behavior in Tidal Low Land of Rice Cultivation with ICM Approach

\begin{tabular}{cccc}
\hline No. & Class Interval Score (Total Score) & Class Interval (Per Indicator) & Value Criteria \\
\hline 1. & $54.00 \times 90.00$ & $1.00 \times 1.66$ & Low \\
2. & $90.00<\times 126.00$ & $1.67<\times 2.33$ & Currently \\
3. & $126.00<\times 162.00$ & $2.34<\times 3.00$ & Tall \\
\hline
\end{tabular}

The calculation of revenue and income used the following equation (Soekartawi, 2002):

$$
\begin{aligned}
& \text { TR = Py. Y } \\
& \pi=\text { TR TC }
\end{aligned}
$$

Where: $\pi=$ Income (IDR); TR = Total revenue (IDR); TC = Total cost (IDR); Py = Price of $Y$ $(\mathrm{IDR} / \mathrm{kg}) ; \mathrm{Y}=$ Total production $(\mathrm{kg})$.

To analyze the correlation between farmers' behavior and rice farming income in tidal low land, the Pearson Product Moment Correlation Test was used with SPSS 16.0 Software. To find the correlation coefficient, it uses the following formula (Riduwan in Bertan, 2016):

$$
r=\frac{\mathrm{n} \sum \mathrm{XY}-\left(\sum \mathrm{X}\right)\left(\sum \mathrm{Y}\right)}{\sqrt{\left[n \sum X^{2}-\left(\sum X\right)^{2}\right]\left[n \sum Y^{2}-\left(\sum Y\right)^{2}\right]}}
$$


The hypotheses used in this study are:

- HO: There is no significant correlation between farmers' behavior and tidal low land rice farming income;

- $\mathrm{H} 1$ : There is a significant correlation between farmers' behavior and tidal low land rice farming income.

\section{RESULTS AND DISCUSSION}

\section{The Level of Farmers' Behavior in Tidal Low Land Rice Farming with Integrated Crop Management Approach (ICM)}

Technological innovation with the ICM approach is aimed at farming efficiency and increasing productivity while minimizing the use of chemicals to support sustainable agriculture. The level of behavior of farmers in rice cultivation in tidal low land with the ICM approach in Muara Telang District, Banyuasin Regency was analyzed using 3 (three) indicators, namely (1) knowledge, (2) attitude and (3) skill. There are 8 (eight) components that represent ICM technology: (1) New superior varieties (VUB) and quality and labeled seeds, (2) Land preparation, (3) Planting, (4) Micro water management, (5) Balanced fertilization based on plant needs and soil nutrient status, (6) Amelioration, (7) Plant Pests and Deseases control, and (8) Harvest (Table 4).

Table 4 - The Level of Farmers' Behavior in Tidal Low Land Rice Cultivation Technology with the ICM Approach in Muara Telang District, Banyuasin Regency in 2021

\begin{tabular}{|c|c|c|c|c|c|c|c|c|c|}
\hline No. & Indicator & Knowledge & Criteria & Attitude & Criteria & Skills & Criteria & Behavior & Criteria \\
\hline 1. & $\begin{array}{l}\text { New Superior } \\
\text { Varieties (VUB) } \\
\text { as well as } \\
\text { quality and } \\
\text { labeled seeds }\end{array}$ & 12.13 & High & 12.90 & High & 11.14 & Medium & 37.09 & High \\
\hline 2. & $\begin{array}{l}\text { Land } \\
\text { preparation }\end{array}$ & 4.91 & High & 5.19 & High & 4.78 & High & 14.88 & High \\
\hline 3. & Planting & 4.19 & Medium & 4.60 & Medium & 3.43 & Medium & 12.22 & Medium \\
\hline 4. & $\begin{array}{l}\text { Micro water } \\
\text { management }\end{array}$ & 4.67 & High & 5.34 & High & 4.60 & Medium & 14.61 & High \\
\hline 5. & $\begin{array}{l}\text { Balanced } \\
\text { fertilization }\end{array}$ & 6.56 & Medium & 6.91 & Medium & 6.24 & Medium & 19.71 & Medium \\
\hline 6. & Amelioration & 2.33 & Medium & 2.30 & Medium & 2.15 & Medium & 6.78 & Medium \\
\hline 7. & $\begin{array}{l}\text { Pest and } \\
\text { Disease }\end{array}$ & 2.15 & Medium & 2.33 & Medium & 2.02 & Medium & 6.50 & Medium \\
\hline \multirow[t]{2}{*}{8.} & $\begin{array}{l}\text { Control } \\
\text { Harvest }\end{array}$ & 5.42 & High & 5.95 & High & 5.60 & High & 16.97 & High \\
\hline & Amount & 42.36 & High & 45.52 & High & 39.96 & Medium & 128.73 & High \\
\hline
\end{tabular}

The results showed that the level of farmers' behavior towards tidal low land cultivation technology with the ICM approach was in the high criteria with a score of 128.73. These results indicate that farmers in Muara Telang District have good behavior in tidal low land rice cultivation with the ICM approach.

Table 4 above shows that farmers have high attitudes towards VUB technology as well as quality and labeled seeds, land management, micro water management and harvesting. Meanwhile, the level of farmer behavior towards the other 4 technologies in the form of planting, balanced fertilization, amelioration and pests and deseases control are in the medium criteria. This condition is thought to be caused by several factors such as the availability of site-specific VUB, limited capital, farmers' preferences in planting systems that prefer the direct seed planting system by dispersed method compared to the "jajar legowo" planting system and limited ability to use the equipment of Swamp Soil Test and laboratory analysis as well as habits in the use of chemical pesticides as the first choice in controlling plant pests and deseases.

Knowledge, attitudes and skills are components that create behavior. Judging from each indicator, there are 4 (four) indicators where the knowledge and attitudes of farmers are 
in high criteria, namely New Superior Varieties (VUB) and quality and labeled seeds, land management, micro water management and harvesting. Farmers understand and agree that VUB has advantages such as high productivity, resistance to biotic and abiotic environments and resistance to plant pests and diseases. Farmers' understanding of the Inpara varieties (eg. Inpara 2, Inpara 4 and Banyuasin) and several Inpari varieties (eg. Inpari 6, Inpari 20, Inpari 30, Inpari 38 and Inpari 48) as new high yielding varieties specific to tidal low land is classified as good. Various VUB specific to tidal low lands have long been introduced and disseminated by various institutions through various dissemination programs and activities so that it increases knowledge and generates positive attitude towards this component of technology. Mendis, et al. (2013) stated farmers' preferences in choosing rice varieties based on yield potential, number of empty seeds, resistance to pests and diseases and the amount of final consumer demand (type of rice). In line with this opinion, Rusyadi (2014) and Koes (2013) state that the main factors that create farmers' attitude in buying seeds are yield potential, resistance to pests and diseases and age of seed plants. The role of demographic, economic, social, cultural, family, psychological and other factors also determines the role.

Farmers' knowledge and attitude towards land management are also in high criteria. Farmers understand and agree that the stages of the land management process are carried out in 2 stages, namely the soil is flooded so that toxic substances are separated from the soil with the puddle water height ranging from $5-10 \mathrm{~cm}$. The second stage is carried out two weeks after the first processing with a tillage depth of about $20-25 \mathrm{~cm}$.

The next indicator is micro water management. The results of the analysis show that the knowledge and attitude of farmers towards this technology component are also in high criteria. Farmers know and believe that the micro water system consists of tertiary, quaternary, circular canals and wormholes. Water management is carried out mainly based on the type of overflow, with the principles of meeting the water needs of plants, preventing oxidation of the pyrite layer, washing out toxic materials, maintaining peat moisture and preventing saltwater intrusion.

The level of knowledge and attitude of farmers towards harvesting technology is also high. Farmers have a good understanding and positive attitude towards this technology. Farmers know and agree that harvesting is done when $90-95 \%$ of the panicles turn yellow. Farmers also know and agree to the use of combine harvester machines.

Knowledge describes how the level of understanding of farmers in accessing and obtaining various information on technological innovations. Farmers who have high knowledge also have a high level of awareness. The high awareness of farmers encourages farmers to increase their knowledge to be more empowered. The formation of attitudes starts from the stage of forming an individual's knowledge through the process of a perception. This attitude will then encourage the delivering of actions in the form of skills. Good insight and understanding from individual farmers will encourage the formation of a positive attitude which in turn can change the behavior of farmers in farming. In line with this opinion, Pratiwi and Sudrajat (2012) stated that the higher the level of education completed by individual farmers, the wider the mindset. The high level of knowledge of these farmers helps efforts to cultivate environmentally friendly agriculture. The results showed that the knowledge of farmers has an important role in efforts to build sustainable agriculture. Shohib et al. (2016) which states that the formation of farmer knowledge to become action through several stages, namely the stages of knowing, understanding, applying, analyzing and evaluating.

Suryani (2013) states that attitudes are born from the process of learning, observing and formulating everything in the environment. Darmawan et al. (2021) stated that in the adoption stage of attitudes, farmers struggle to get more information when they can accept the knowledge conveyed and seek information about the advantages and disadvantages of it. Attitudes are formed from the birth of perceptions that begin with knowledge which is influenced by several factors such as experience, learning process, insight and knowledge (Sedana, 2013). This positive attitude of farmers is because farmers are open to new information. According to Azwar (2003) that a person's attitude towards an object is a feeling to support and not support a certain object that is seen or carried out. In the results of research Mayalibit et al. (2017) explained that age, formal education, experience, influence 
from other people who are considered important, and the influence of mass media are some of the factors that influence farmers' attitudes. Attitudes are fundamental in building behavior and greatly determine the decision process.

Skills are formed through the process of forming knowledge and attitude that can be seen from the real actions of tidal low land farmers with the ICM approach in Muara Telang District. From Table 4 above, it can be explained that the skill level of farmers towards the ICM technology component is in the medium criteria. This shows that farmers are quite good at applying the components of ICM technology.

Farmers do not always use VUB in every growing season. The use of existing seeds is based on the availability of seeds that are easily obtained by farmers. Limited capital to buy superior and labeled seeds is also one of the contributing factors. In addition, some farmers still use a lot of seeds in planting. This amount exceeds the recommendation, which is in the range of $60-80 \mathrm{~kg} / \mathrm{ha}$. In the direct seeding system, the number of seeds used will be more. This is in accordance with the results of Darmayanti's research (2018) which reports that the production costs incurred by farmers to buy rice seeds with the direct planting system are greater than the shifting planting system. Farmers' skills in seed treatment are quite good. Farmers treat seeds before planting,

Farmers have good skills in land management, micro water management and harvesting. They have carried out water management based on the type of overflow. They are also used to harvesting when $90-95 \%$ of the panicles have turned yellow. In addition, farmers have also used a combine harvester for harvesting. According to them, the use of this harvesting machine is very helpful in saving labor costs and facilitating the harvesting process.

The planting system used by farmers is direct seed planting by sowing. Only a small number of farmers carry out planting with the "jajar legowo". Farmers' preference for this cropping system is still low. They tend to prefer the direct cropping system. "Jajar legowo" is considered by farmers to be more difficult to plant so it takes longer and requires more labor. This is due to the fact that farmers are not familiar with the application of this planting system. If farmers are used to it, the planting process is not difficult and does not take a long time. In the direct planting system, farmers prefer the sowing method. Only a small number of farmers use ticks to help plant and the use of drum seeder is still at the introduction step.

The majority of farmers apply urea fertilization at a dose of $200 \mathrm{~kg} / \mathrm{ha}$. However, farmers are not accustomed to using Swampland Soil Test Kit or conducting laboratory analysis in determining fertilizer doses, especially $\mathrm{P}$ and $\mathrm{K}$ fertilizers. Besides that, farmers are still rarely given organic fertilizers in the amount of 3-4 tons/ha. In addition, farmers also have not implemented the provision of dolomite according to the recommendations. They are also not skilled in controlling pests and diseases in an integrated where pesticide is their first choice. Knowledge, attitude and skill of farmers in controlling pests and deseases in an integrated manner are one of the important factors in rice cultivation. According to Arbi, et al. (2019), there is a positive correlation between farmers' perception and the income of rice farming using ecological engineering (refugia).

Skills are the final process after the knowledge and attitude of farmers are formed. The skill of farmers in cultivating tidal low land with the ICM approach shows the ability of farmers in farming. According to Fadhillah, et al. (2019), the formation of farmer skills is caused by many factors such as experience, age and knowledge of farmers. Knowledge has an indirect effect on farmers' skills because knowledge is the basis of every individual doing something. In line with this opinion, Lestari, et al. (2013) stated that skills are behaviors that are shown based on the knowledge and attitude they have. In the rice management of tidal low land in Muara Telang District, farmers have a high level of knowledge and attitude towards rice cultivation technology with the ICM approach. However, this high level of knowledge and attitude is not accompanied by a high level of application. This is generally due to the limited availability of capital owned by farmers so that it is still difficult to carry out the cultivation stages according to the recommendations.

The high level of behavior describes the level of good ICM implementation that is environmentally friendly. This reflects that farmers have been good in managing their farms 
to build sustainable agriculture. This behavior is formed from a large and deep knowledge of the components of ICM technology, followed by the delivering of a more advanced attitude and more scientific motivation for action so as to realize better farming skills. As stated by Fadhillah, et al. (2019) that the behavior of farmers is manifested in an action that can be seen, formed due to the delivery of knowledge and is passed on to an impulse in the form of an attitude and becomes an activity in the form of farmers' skill.

According to Pratiwi and Sudrajat (2012), farmers have different behaviors in managing agricultural land caused by several factors such as the age of the farmer, the farmer's last education level, the length of farming and the knowledge of the farmer. In line with the opinion of Kusumo, et al. (2018) which states that there are external and internal factors that influence behavior. Internal factors come from within the farmers which are reflected through the characteristics of farmers and farmers' perception of the farming they run. Perception is one of the internal factors that encourage behavior.

The income studied is the deviation between the income earned and the total production cost that have been incurred in tidal low land farming with the ICM approach in Muara Telang District (Table 5) from farming carried out in 2 (two) growing seasons, first season in October 2020 - January 2021 and second season in February - May 2021.

Table 5 - Tidal Low Land Rice Farming Income in Muara Telang District, Banyuasin Regency in 2021

\begin{tabular}{|c|c|c|c|c|}
\hline No. & Description & Amount (Units/Year) & $\begin{array}{c}\text { Price/Unit/Year } \\
\text { (Rp) }\end{array}$ & $\begin{array}{c}\text { Total per Year } \\
(\mathrm{Rp})\end{array}$ \\
\hline A. & Total cost & & & $16,665,904$ \\
\hline \multirow[t]{6}{*}{1.} & Tool depreciation cost & & & 274.334 \\
\hline & - Sickle & 1 & 17,224 & 17,224 \\
\hline & - $\quad$ Hoe & 1 & 28.326 & 28.326 \\
\hline & - Machete & 1 & 17,850 & 17,850 \\
\hline & - Manual hand sprayer & 1 & 92.756 & 92.756 \\
\hline & - Machine hand sprayer & 1 & 118.178 & 118.178 \\
\hline \multirow[t]{4}{*}{2.} & Tools and machines rental & & & $5,600,000$ \\
\hline & 2-wheel tractor & 2 & 800,000 & $1,600,000$ \\
\hline & 4-wheel tractor & 2 & 900,000 & $1,800,000$ \\
\hline & Combine harvester & 1 & $2,200,000$ & $2,200,000$ \\
\hline 3. & Seeds $(\mathrm{kg})$ & 120 & 14,000 & $1,680,000$ \\
\hline \multirow[t]{5}{*}{4.} & Chemical fertilizer $(\mathrm{kg})$ & & & $2,437,500$ \\
\hline & Urea & 335 & 2,500 & 837,500 \\
\hline & NPK & 400 & 2,300 & 920,000 \\
\hline & SP-36 & 140 & 2,000 & 280,000 \\
\hline & $\mathrm{KCl}$ & 50 & 8.000 & 400,000 \\
\hline 5. & Dolomite $(\mathrm{kg})$ & 500 & 1,400 & 700,000 \\
\hline 6. & Herbicide (I) & 13.66 & 88.000 & 1.202 .080 \\
\hline 7. & Fungicide (I) & 2.33 & 333,000 & 775,890 \\
\hline 8. & Insecticide (I) & 3.83 & 270,000 & $1,034,100$ \\
\hline 9. & Sacks (unit) & 160 & 3,000 & 480,000 \\
\hline \multirow[t]{6}{*}{10.} & Labor cost (HOK) & & & $2,482,000$ \\
\hline & Plant & 4.00 & 125,500 & 502,000 \\
\hline & Stitching & 5.00 & 110,000 & 550,000 \\
\hline & Fertilizing 3 times & 5.00 & 110,000 & 550,000 \\
\hline & Spraying 2 times & 4.00 & 110,000 & 440,000 \\
\hline & Weeding 2 times & 4.00 & 110,000 & 440,000 \\
\hline B. & Productivity (Kg/Ha/Year) & & & 10,483 \\
\hline C. & Selling Price $(\mathrm{Rp} / \mathrm{kg})$ & & & 4,000 \\
\hline D. & Revenue (Rp/Ha/Year) & & & $41,932,000$ \\
\hline $\mathrm{E}$. & Income (Rp/Ha/Year) & & & $25,226,096$ \\
\hline
\end{tabular}

Source: Primary data processed (2021).

In the management of tidal low land rice farming in Muara Telang District, farmers incur fixed costs in the form of depreciation costs for the tools used during the cultivation process. The depreciation costs of the tools calculated include sickles, hoes, machetes, manual handsprayer and machine handsprayer. These tools are used by farmers to assist the 
cultivation process carried out. In 1 year, the cost of equipment depreciation incurred in the rice cultivation of tidal low land in Muara Telang District for a land area of 1 ha is Rp. 274.334. Farmers also incur variable costs, one of which is the cost of renting machinery, namely 2-wheel tractor, 4-wheel tractor and combine harvester. In land preparation, farmers use 2-wheel and 4-wheel tractors. Meanwhile, combine harvesters are used at harvest time. The use of machine tools in rice farming is very necessary in an effort to overcome labor limitations and improve the quality of yields (especially in soil processing, planting and harvesting activities). As the results of research by Pipit et al. (2021) who reported that the use of a combine harvester can improve the quality of grain and the final yield of rice products. This affects the behavior change of farmers to adopt agricultural mechanization.

Payment for tractor rental is made after harvest (calles as "yarnen"). Farmers only need to pay an advance of $25-30 \%$ and the rest is paid after harvest. The use of tractor machinery is able to motivate farmers to use other technologies more objectively. For combine harvesters, farmers usually rent in the form of profit sharing (called as "bawon" system) as much as $1 / 8$ or $1 / 9$ of the harvest. The costs incurred include all costs including operator, labor and diesel oil costs. This tractor and combine harvester rental usually comes from the Agricultural Tools and Machines Service Business (UPJA), both managed by individuals and farmer groups. According to Zepri et al. (2020), there is no significant difference in productivity and income between farmers who use UPJA services and those who use other rental services.

Table 5 also informs that the costs incurred by farmers to buy production facilities are $49.86 \%$, labor costs are $14.89 \%$ and the cost of buying and renting machinery and equipment is $35.25 \%$ of the total cost. The largest production costs are for the purchase of pesticides, then fertilizers and seeds.

The largest labor costs incurred are at the time of embroidery because farmers need a long time. The limited labor force for planting causes farmers to get used to direct seed planting (called as "tabela") by spreading it. Although direct seed planting tools (called as "atabela") in the form of ticks and drum seeders have been introduced for a long time (more than 10 years), these tools have not developed quickly. The reason is because according to farmers, this tool does not increase production and can increase the cost of buying.

Table 6 - Pearson's Correlation Test Analysis Results

\begin{tabular}{rlrr}
\hline & & Behavior & \multicolumn{2}{c}{ Income } \\
\hline Behavior & Pearson Correlation & 1 & $.458^{\star *}$ \\
& Sig. (2-tailed) & & .000 \\
\multirow{3}{*}{ Income } & $\mathrm{N}$ & 150 & 150 \\
& Pearson Correlation & $.458^{\star \star}$ & 1 \\
& Sig. (2-tailed) & .000 & \\
& $\mathrm{~N}$ & 150 & 150 \\
\hline
\end{tabular}

${ }^{* *}$. Correlation is significant at the 0.01 level (2-tailed).

From Table 5 it can be seen that the amount of income obtained by farmers from tidal low land rice farming with the ICM technology approach in 1 year has a positive value of Rp. $25,226,096 / \mathrm{Ha}$. This means that farmers benefit from the farming they do. The cropping pattern that farmers generally do in Muara Telang District consists of Padi-Rice-Palawija (Maize). In second rice planting seasons, the profits obtained by farmers are positive. The value of income obtained by farmers in first seasin is $39.84 \%$ greater than second season. It was caused by a higher level of income which was influenced by higher productivity and selling prices. This difference in productivity level was caused by the higher attack of pests and diseases on second season in the form of rats and leafhoppers but the level of control carried out was low. The results of the research by Pamungkas, et al. (2020) stated that the low productivity of rice was caused by high pest and disease attacks and integrated control has not been carried out properly. Likewise, the selling price of grain is lower in second season. The price of grain tends to fluctuate. It was caused by simultaneous harvesting with 
other regions. In line with the annual production pattern, at the location of production centers, grain production at harvest time is always abundant, while demand for unhulled rice/rice tends to be stable.

Analysis of the correlation between the level of farmers' behavior in rice cultivation with the ICM approach to farming income in tidal low land was analyzed using the Pearson Correlation Test (Table 6).

The results of the analysis show that there is a significant and positive correlation between the behavior of farmers in rice cultivation with the ICM approach and the income of rice farming in tidal low land at a significance level of 0.000 with a correlation magnitude of 0.458 . This shows that the higher the behavior of farmers in rice cultivation with the ICM approach, the higher the income of rice farming in tidal low land. The results of the analysis also show that the level of farmer behavior affects farm income by $45.8 \%$ while the remaining $54.2 \%$ is influenced by other variables not measured in this study. High knowledge, attitude and skill of farmers will affect the level of implementation of good farming so that it has an impact on increasing productivity which in turn increases farmers' income.

Rambe and Honorita $(2011)$ revealed that the knowledge and attitude response to a change was not given directly, due to the influence of experience, length of farming and the monopolized environment of farmers in a tidal swamp rice farming activity for generations. Meanwhile, farmer skills describe the capabilities and activities that farmers have which are manifested in the high level of application of tidal swamp rice cultivation. The results of research conducted by Darmawan et al. (2021) reported that farmers' behavior which includes knowledge, attitude, and skill has a simultaneous influence on rice productivity by $45.7 \%$.

\section{CONCLUSION}

From the analysis carried out in this study, it can be concluded that the level of farmers' behavior in tidal low land rice cultivation with the ICM approach is at a high criteria with an income of Rp. 25,226,096 per hectare per year. The results of the analysis also conclude that there is a significant and positive correlation between the level of farmers' behavior and the income of rice farming in tidal low land as big as $45.8 \%$. The higher the behavior of farmers, the greater the income obtained.

From the results of this study, programs and activities to empower human capital that linked with the existence of social capital in the farmer's environment are part of the recommendations that are quite important in changing farmers' behavior to increase rice productivity in tidal low lands.

\section{REFERENCES}

1. Alihamsyah, T., M, Sarwani and I. Ar. Riza. 2003. Lahan Pasang Surut Sebagai Sumber Produksi Padi Masa Depan. Dalam Kebijakan Perberasan dan Inovasi Teknologi Padi. Buku dua. Pusat Penelitian dan Pengembangan Tanaman Pangan, Balai Penelitian Tanaman Padi Sukamandi. Hal. 263-287.

2. Ananto, E.E., A. Supriyo, Soentoro, Hermanto, Y. Sulaiman, I.W Suastika and B. Nuryanto. 2000. Pengembangan Usaha Pertanian Lahan Pasang Surut Sumatera Selatan: Mendukung Peningkatan Produksi Pangan. Badan Litbang Pertanian. Departemen Pertanian. 166p.

3. Arbi M., Januarti I., Junaidi N., Yulius and Sari N S. 2019. The Farmer's Perception Towards The Integrated Pest Control Based on Ecological Engineering in Karang Sari Village of Belitang East OKU Regency, Indonesia. RJOAS, 12(96), December 2019.

4. Azwar, Saifuddin. 2000. Sikap Manusia Teori dan Pengukurannya. Edisi ke 2. Cetakan IV. Pustaka Pelajar. Yogyakarta.

5. Central Bureau Statistic of Banyuasin District. 2018. Muara Telang dalam Angka. Central Bureau Statistic of Banyuasin District.

6. Central Bureau Statistic of South Selatan. 2019. Sumatera Selatan dalam Angka. Central 
Bureau Statistic of South Selatan.

7. Darmawan A., Gayatri S and Satmoko S. 2021. Pengaruh Perilaku Petani dalam Penerapan Sapta Usahatani Terhadap Produktivitas Padi di Kelompok Tani Vanda Subur, Kota Semarang. Jurnal Litbang Provinsi Jawa Tengah Vol. 19 No. 1 Juni 2021, hal 37-48.

8. Fadhillah, L E., Satmoko $S$ and Dalmiyatun T. 2019. Pengaruh Perilaku Petani Padi Terhadap Penggunaan Benih Padi Bersubsidi di Desa Tlogoweru Kecamatan Guntur Kabupaten Demak. Jurnal Ekonomi Pertanian dan Agribisnis (JEPA) Volume 3, Nomor 2 (2019): 408-418.

9. Groves, Robert M. Survey Methodology (2010), ISBN 0-471-48348-6.

10. Indonesian Agency of Agricultural Research and Development. 2007. Petunjuk Teknis Lapang Pengelolaan Tanaman Terpadu (PTT) Padi Lahan Rawa Pasang Surut. Kementerian Pertanian.

11. Koes A. 2013. Analisis Sikap, Kepuasan Dan Loyalitas Petani Terhadap Penggunaan Benih Unggul Jagung Komposit Di Sulawesi Selatan. [Tesis]. Program Pasca Sarjana. Institut Pertanian Bogor. Bogor.

12. Kusumo, R A B., Rasmikayati E, and Mukti G W. 2018. Perilaku Petani dalam Usahatani Mangga di Kabupaten Cirebon. Mimbar Agribisnis. Jurnal Pemikiran Masyarakat IImiah Berwawasan Agribisnis.

13. Lestari, W., D. Rabesdini and J. Yusri. 2013. Respon Petani Terhadap Program Sekolah Lapang Pengelolaan Tanaman Terpadu (SL-PTT) Padi Sawah di Desa Pulau Birandang Kecamatan Kampar Timur Kabupaten Kampar. J. Agribisnis. 1-15.

14. Mayalibit, N F., Suwarto, Rusdiyana, E and Wijianto, A. 2017. Sikap Petani Terhadap Benih Padi Unggul Bersertifikat di Kecamatan Karangpandan, Kabupaten Karanganyar. Caraka Tani: Journal of Sustainable Agriculture. 2017. 32(2), 116 - 125.

15. Mendis S, Edirisinghe JC. 2013. Willingness to Pay for Rice Traits in Kurunegala and Hambantota Districts: an Application of a Spatial Hedonic Pricing Model. The Journal of Agricultural Sciences, 2013, vol.8, no.1.

16. Pipit W., Acmadi S and Susantinah W N. 2021. Farmers' Attitude and Rice Added Value Based on Agricultural Mechanization in East Java of Indonesia. RJOAS, 4(112), 2021.

17. Pratiwi, E F and Sudrajat. 2012. Perilaku Petani dalam Mengelola Lahan Pertanian di Kawasan Rawan Bencana Longsor. Jurnal Bumi Indonesia Vol. 1 Nomor 3 Tahun 2012.

18. Rambe S S and Honorita B. 2011. Perilaku Petani dalam Usahatani Padi di Lahan Rawa Lebak. Prosiding Seminar Nasional Budidaya Pertanian. Urgensi dan Strategi Pengendalian Alih Fungsi Lahan Pertanian. 7 Juli 2011 ISBN 978-602-19247-0-9.

19. Rawung, Dede Trinovie. 2020. Bahan Ajar Diklat Statistisi Ahli BPS Angkatan XXI Tahun 2020: Metode Penarikan Sampel. Pusat Pendidikan dan Pelatihan Badan Pusat Statistik.

20. Ruslan. 2007. Trust: Kebajikan Sosial dan Penciptaan Kemakmuran (terjemahan). Penerbit Qalam. Yogyakarta.

21. Rusyadi Y. 2014. Analisis Sikap Dan Kepuasan Petani Terhadap Atribut Benih Padi Hibrida Maro Di Kabupaten Subang Jawa Barat. [Tesis]. Program Pasca Sarjana. Institut Pertanian Bogor. Bogor (ID).

22. Sedana, G. 2013. Sikap Petani Terhadap Fermentasi Biji Kakao: Kasus pada Subakabian Buana Mekar, Desa Angkah Kabupaten Tabanan. J. Dwijenagro, 3 (2): 1-6.

23. Shohib, M. N., MG. C. Yuantari and M. Suwandi. 2016. Hubungan Antara Pengetahuan dan Sikap dengan Praktik Pemakaian (APD) Alat Pelindung Diri pada Petani Pengguna Pestisida di Desa Curut Kec. Penawang Kab. Grobogan tahun 2013. Universitas Dian Nuswantoro. Semarang.

24. Suriadikarta D A and Sutriadi. 2007. Jenis-Jenis Lahan Berpotensi untuk Pengembangan Pertanian di Lahan Rawa. Jurnal Penelitian \& Pengembangan Pertanian 26(3):115-122.

25. Suryani, T. (2013). Perilaku Konsumen di Era Internet: Implikasinya pada Strategi Pemasaran. GRAHA ILMU.

26. Zepri A., Andy M and Yunita. 2020. Performance Analysis of Rice Farming Utilizing Agricultural Equipment Machinery Rental Services in Muara Telang District of Banyuasin. RJOAS 6(102), Juni 2020. 